\title{
Upaya Bank Dan Otoritas Jasa Keuangan Mencegah Kredit Bermasalah Pada Kredit Usaha Rakyat
}

\author{
Dea Amnitra Syahid Hidayatullah \\ Magister Hukum Fakultas Hukum Universitas Islam Indonesia Yogyakarta Indonesia \\ Jln. Cik Di Tiro No. 1 Yogyakarta Indonesia \\ damnitra@gmail.com
}

\begin{abstract}
Efforts made by banks, especially BRI, in dealing with non-performing loans are inseparable from various factors. The fact that the provision of people's business credit is not accompanied by security and/or guarantees is seen from the Collateral aspect where collateral is goods, assets or securities used as collateral. The research, which was conducted using a sociological approach, found that in the present case, the borrower responded to the lender (the bank) and aimed to provide security for the loan. This study concludes, first, that Bank BRI Kartosuro branch itself still refers to the $5 \mathrm{C}$ principles in the credit process, namely: Character, Capacity, Capital, Condition and Collateral and the classification of non-performing loans refers to the criteria provided by Bank Indonesia, namely in accordance with Article 4 of the Decree of the Director of the Bank. Indonesia Number 30/267/KEP/DIR, dated February 27, 1998. Second, the Financial Services Authority (OJK) and Bank of Indonesia may coordinate by cooperating in joint supervision of financial service activities in the banking sector. OJK has the authority to conduct investigations in the financial services sector, including banking.
\end{abstract}

Key Word: Bank; KUR; MSME; OJK

\begin{abstract}
Abstrak
Upaya yang dilakukan bank khususnya BRI dalam menangani kredit bermasalah tidak terlepas dari berbagai faktor. Fakta bahwa pemberian kredit usaha rakyat ini tidak disertai dengan agunan dan/atau jaminan melihat secara aspek Collateral yang dimana agunan adalah barang, aset atau surat berharga yang digunakan sebagai jaminan. Penelitian yang dilakukan dengan metode pendekatan sosiologis ini mendapatkan hasil bahwa dalam hal ini peminjam kepada pihak pemberi pinjam (Bank) dan bertujuan untuk memberikan keamanan terhadap pinjaman yang diberikan. Penelitian ini menyimpulkan pertama, bahwa Bank BRI cabang Kartosuro sendiri tetap mengacu pada prinsip 5C dalam proses kredit yaitu: Character, Capacity, Capital, Condition and Collateral dan pada penggolongan kredit bermasalah mengacu menurut kriteria yang diberikan oleh Bank Indonesia yaitu sesuai dalam Pasal 4 Surat Keputusan Direktur Bank Indonesia Nomor 30/ 267/ KEP/ DIR, tanggal 27 Februari 1998. Kedua, otoritas Jasa Keuangan dan Bank Indonesia dapat berkoordinasi dengan bekerjasama dalam pengawasan bersama atas kegiatan jasa keuangan di bidang perbankan. OJK mempunyai wewenang untuk melakukan penyidikan di sektor jasa keuangan termasuk perbankan.
\end{abstract}

Kata-kata Kunci: Bank; OJK; KUR; UMKM 


\section{Pendahuluan}

Pembangunan nasional di bidang perekonomian yang maju dapat diindikasikan dari bergeraknya perekonomian masyarakat dan dunia usaha. Salah satu faktor yang menunjang dalam pembangunan dibidang perekonomian adalah sektor jasa keuangan. Sektor ini sendiri terdiri dari berbagai lembaga keuangan yang merupakan suatu perusahaan yang usahanya bergerak dibidang jasa keuangan. Artinya kegiatan yang dilakukan oleh lembaga ini akan selalu berkaitan dengan bidang keuangan, yang terdiri dari penghimpunan dana, menyalurkan, dan/atau jasa keuangan lainnya. Sektor jasa keuangan merupakan salah satu industri yang berkembang pesat dan memiliki kompleksitas operasional serta tingkat kompetisi yang tinggi.

Hal tersebut menyebabkan industri keuangan jadi sangat berisiko, sehingga harus beroperasi secara hati-hati dan efisien dan Pasar keuangan yang sedemikian pesat terutama di topang dengan teknologi dan inovasi produk keuangan telah menciptakan sistem keuangan yang sangat kompleks, dinamis serta saling terkait antar sub-sektor keuangan baik atas produk yang dipasarkan maupun secara kelembagaan. ${ }^{1}$ Sektor keuangan di Indonesia saat ini telah mengarah pada konglomerasi, dengan ditandainya konsolidasi perbankan yang mengarahkan jumlah bank semakin mengecil, tetapi jumlah cabang beserta aset dan kreditnya semakin meningkat. Tanda lainnya adalah dengan berkembangnya sektor keuangan nonbank yang terafiliasi dengan bank, terutama sektor pembiayaan (multifinance) dan asuransi. Akibat dari tanda tersebut adalah sektor keuangan menjadi tidak responsif terhadap kebijakan. ${ }^{2}$

Sektor ini merupakan bagaian dari suatu badan usaha yang bergerak dalam bidang keuangan. Badan usaha ini di kenal sebagai lembaga keuangan yang kegiatan utamanya menerima simpanan, tabungan dan deposito. Di samping itu, badan usaha ini juga dikenal sebagai tempat meminjam uang (kredit) bagi masyarakat yang membutuhkan, sebagai tempat untuk menukar uang, dan memindahkan uang atau menerima segala macam bentuk pembayaran dan setoran yaitu sektor usaha ini disebut Bank. berdasarkan Pasal 1 UndangUndang Nomor 10 Tahun 1998 tentang perubahan Undang-Undang Nomor 7 Tahun 1992 tentang Perbankan, Bank didefinisikan sebagai badan usaha yang menghimpun dari masyarakat dalam bentuk simpanan dan menyalurkan kepada masyarakat dalam rangka meningkatkan taraf hidup rakyat banyak.

'Tony Rodyanto, "Pengawasan Terintegrasi Lembaga Jasa Keuangan Suatu Tinjauan Umum", https:/ / tonyrodyanto.wordpress.com/2014/09/08/pengawasan-terintegrasilembaga-jasa-keuangan-suatutinjauan-umum/. Diakses pada 12 Oktober 2014.

2 Paripurna P. Sugarda, Ringkasan Disertasi Pengaturan Sistem Pengawasan Perbankan Berdasarkan Prinsip Kehatibatian di Indonesia, Universitas Gadjah Mada, Yogyakarta, 2012. 
Melalui kegiatan perkreditan dan berbagai jasa yang diberikan, bank melayani kebutuhan pembiayaan serta melancarkan mekanisme sistem pembayaran bagi semua sektor perekonomian. Sistem perbankan Indonesia, berdasarkan Undang-Undang Nomor 7 Tahun 1992 tentang Perbankan sebagaimana telah diubah dengan Undang-Undang Nomor 10 Tahun 1998 tentang perubahan atas Undang-Undang Nomor 7 Tahun 1992 tentang Perbankan serta Undang-Undang Nomor 21 Tahun 2008 tentang Perbankan Syariah. ${ }^{3}$ Agar Bank dapat melaksanakan tugasnya sesuai peraturan, maka Bank harus tunduk pada undang-undang perbankan, yang bertujuan menumbuh kembangkan Bank yang sehat dan kuat.

Bank juga harus tunduk pada Kebijakan Umum Perkreditan, sesuai ketentuan yang diatur dalam PBI (Peraturan Bank Indonesia). Kebijakan Umum Perkreditan (KUP) ini merupakan kebijakan perkreditan, sesuai dengan prinsipprinsip manajemen mencakup perencanaan, pengorganisasian, pelaksanaan dan pengawasannya. Bank harus menjabarkan KUP dalam bentuk Sistem Operasional Perkreditan (SOP) atau Pedoman Pelaksanaan Perkreditan (PPK), yang merupakan petunjuk operasional dalam pelaksanaan perkreditan yang dapat menjamin kredit yang sehat.

Otoritas Jasa Keuangan selanjutnya disingkat (OJK) juga merupakan lembaga independen dan bebas dari campur tangan pihak lain. OJK mempunyai fungsi, tugas, dan wewenang pengaturan, pengawasan, pemeriksaan, dan penyidikan di sektor jasa keuangan sebagaimana dimaksud dalam UndangUndang Republik Indonesia Nomor 21 Tahun 2011 tentang OJK.

Lembaga perbankan dalam melaksanakan perkreditan tidak jarang ada kredit-kredit yang bermasalah, hal ini menjadikan suatu evaluasi yang harus di benahi di dalam perbankan, agar pelaksanaan perkreditan dapat berjalan dengan baik, baik dari kreditur maupun debitur. Melihat pelaksanaan perkreditan yang bermasalah tersebut bagaimana pengawasan yang dilakukan oleh OJK selaku lembaga independen yang melakukan pengawan keuangan. Jika implementasi kredit bermasalah seharusnya sudah ada Kebijakan Umum Perkreditan (KUP) merupakan kebijakan perkreditan, sesuai dengan prinsip-prinsip manajemen mencakup perencanaan, pengorganisasian, pelaksanaan dan pengawasannya.

Bank harus menjabarkan KUP dalam bentuk Sistem Operasional Perkreditan (SOP) atau Pedoman Pelaksanaan Perkreditan (PPK), yang merupakan petunjuk operasional dalam pelaksanaan perkreditan yang dapat menjamin kredit yang sehat ini, dengan seperti ini seharusnya perbankan dalam

${ }^{3}$ Hermansyah, Hukum Perbankan Nasional Indonesia, Cetakan ke-6 Kencana, Jakarta, 2011, hlm. 7 
melaksanakan perkreditan dapat berjalan baik. ${ }^{4}$ Tetapi pada prektiknya masih ada kredit bermasalah, maka dalam hal ini OJK selaku lembaga pengawasan keuangan bagaimana melakukan pengawasan atas penyaluran kredit usaha rakyat di bank rakyat indonesia.

Permasalahan sektor yang banyak timbul terhadap perkreditan Bank terutama yang menjadikan permasalahaan saat ini, masyarakat sangat mudah tergiur dengan program Kredit Usaha Rakyat (KUR) agar dapat berjalan dengan sehat. Urgensinya dari masyarakat yang tergiur atas program tersebut yang menyebabkan banyak yang harus di evaluasi terhadap KUR. Evaluasi pada tahun 2018-2019 yang dilakukan Kementerian Keuangan ${ }^{5}$ yaitu atas kebijakan KUR, pemerintah berharap program ini mampu dimanfaatkan untuk kegiatan yang bersifat investasi bagi pengembangan bisnis UMKM.

Tak salah jika alokasi KUR setiap tahunnya terus dinaikkan. Jika di 2018 alokasinya sebesar Rp. 117.000.000.000.000,00 maka di 2019 dinaikkan menjadi Rp. 140.000.000.000.000,00. Dikembangkan juga perluasan bidang pemanfaatan KUR misalnya untuk sektor pariwisata yang meliputi agen perjalanan wisata, sanggar seni, penyelenggaraan Meeting, Incentive, Convention, and Exhibition (MICE), penyediaan makanan dan minuman, jasa informasi pariwisata. Selain itu juga KUR dapat menyasar usaha pengelolaan tempat wisata, jasa konsultan pariwisata, usaha jasa pramuwisata, wisata tirta, jasa transportasi pariwisata, industri kerajinan dan oleh-oleh.

Realisasi penyerapan KUR ternyata masih banyak nyangkut di sektor nonproduktif. Menurut data yang dihimpun dari beberapa pihak, hingga November 2018 realisasi KUR produktif masih di bawah 50\%. Pihak perbankan sebagai lembaga penyalur menyebutkan, rendahnya penyaluran di sektor produktif tersebut lebih disebabkan adanya faktor kehati-hatian. Mereka juga menambahkan bahwa potensi kredit macet di sektor produktif masih relatif besar. Diantara beberapa perbankan yang menjadi penyalur KUR, untuk periode Januari hingga November 2018, Bank Perwakilan Daerah (BPD) Jawa Barat dan Banten tercatat sebagai penyalur KUR produktif terbesar hingga 87\%, disusul Bank Artha Graha sebesar 70\%, BPD Sumatera Barat sekitar 63\% dan BRI Syariah mencapai 56\%.

Deretan perbankan ini mendapatkan plafon yang tidak terlalu besar. Perbankan plat merah utama, BRI tercatat menyalurkan hingga $43 \%$ dengan plafon terbesar Rp. 80.200.000.000.000,00, Bank Mandiri sebesar 44\% dengan plafon Rp. $17.600 .000 .000 .000,00$ dan BNI mencapai $46 \%$ dengan plafon Rp.

${ }^{4}$ Hermansyah, Hukum Perbankan Nasional Indonesia, Cetakan ke-6 Kencana, Jakarta, 2011, hlm. 7

5 Lihat web kementerian keuangan republik indonesia diakses pada 2 Oktober 2019 pukul 23.00 https://www.kemenkeu.go.id/publikasi/artikel-dan-opini/evaluasi-kredit-usaha-rakyat-kur-2018/ 
16.400.000.000.000,00. Di 2020 nanti, pemerintah telah menargetkan proporsi realisasi kredit produktif mencapai 70\% dari total KUR yang disalurkan. ${ }^{6}$ Untuk itu pemerintah juga menyiapkan sanksi bagi perbankan penyalur yang tidak memenuhi ketentuan berupa pengurangan platform KUR 5\% hingga 30\% dari tambahan plafon tahun anggaran berikutnya. Pengelompokan usaha produksi, penyusunan sistem monitoring dan risk assesment mungkin dapat dijadikan salah satu opsi pencapaian target proporsi $70 \%$ di 2020. Keberhasilan realisasi penyaluran KUR akan menjadikan APBN sebagai instrumen yang kredibel dan terpercaya di Indonesia. Ketika nantinya APBN mampu menjaga kredibilitasnya maka disitulah masyarakat akan merasakan dampak optimal kehadiran negara secara seutuhnya.

Perlu mengetahui pengawasan OJK terhadap penyaluran kredit bank. Peran OJK sebagai yang mampu melindungi sistem perbankan dari dampak negatif kredit bermasalah dan menciptakan kerangka pengawasan yang mampu memastikan terciptanya stabilitas sistem keuangan secara keseluruhan, maka penulis kemudian tertarik untuk melakukan penulisan hukum dengan judul Upaya Bank Dan Otoritas Jasa Keuangan (OJK) Dalam Mencegah Kredit Bermasalah Pada Program Kredit Usaha Rakyat (KUR) Di BRI Cabang Solo Kartasura.

\section{Rumusan Masalah}

Berdasarkan latar belakang tersebut, maka dapat diidentifikasikan masalah sebagai berikut: pertama, bagaimana upaya bank apabila Kredit Usaha Rakyat (KUR) menjadi kredit bermasalah? Kedua, bagaimana OJK mengawasi penyaluran Kredit Usaha Rakyat (KUR) agar tidak menjadi bermasalah?

\section{Tujuan Penelitian}

Berdasarkan latar belakang tersebut, maka dapat diidentifikasikan tyjyan penelitian sebagai berikut: pertama, mengetahui dan menganalisis upaya yang dilakukan Bank pada kredit bermasalah. Kedua, mengetahui pengawasan yang dilakukan OJK dalam penyaluran kredit usaha rakyat bank agar tidak terjadi kredit bermasalah di Indonesia.

\section{Metode Penelitian}

Pada metode penelitian ini, peneliti menggunakan metode pendekatan Sosiologis. Cara pengambilan data dilakukan dengan menggunakan data primer

${ }^{6}$ Lihat web kementerian keuangan republik indonesia diakses pada 2 Oktober 2019 pukul 23.00 https://www.kemenkeu.go.id/publikasi/artikel-dan-opini/evaluasi-kredit-usaha-rakyat-kur-2018/ 
dan sekunder dari Bank Rakyat Indonesia (BRI) Cabang Solo Kartosuro. Kemudian data yang diperoleh dalam penelitian ini dianalisis dengan menggunakan metode analisis data kualitatif.

\section{Hasil Penelitian dan Pembahasan}

\section{Upaya Bank Mencegah/Mengatasi Kredit Usaha Rakyat (KUR) Bermasalah}

Berdasarkan hasil penelitian penulis di kantor Bank Rakyat Indonesia (BRI) Cabang Solo Kartosura serta hasil wawancara yang dilakukan penulis dengan Kepala Unit, Mantri (Account Officer/AO) serta dua orang nasabah KUR, maka penulis dapat mengemukakan bahwa proses pemberian KUR dilakukan secara bertahap yaitu sebagai berikut:

\section{Tahap Permohonan Kredit}

Calon debitur mengajukan permohonan kredit usaha rakyat (KUR) secara tertulis kepada pihak BRI. Calon debitur KUR datang ke kantor BRI, kemudian dengan dibantu oleh Customer Service, calon debitur KUR mengisi formulir pendaftaran atau formulir pengajuan permohonan KUR yang sudah disediakan pihak bank, kemudian ditandatangani oleh pemohon. ${ }^{7}$ Calon debitur kredit usaha rakyat diharuskan memenuhi persyaratan yang telah ditetapkan dalam hal pengajuan permohonan kredit usaha rakyat. Kredit usaha rakyat diperkenalkan sebagai kredit yang mudah didapat, maka syaratsyarat yang ditetapkan pun sangat sederhana. Syarat-syarat yang perlu disertakan adalah bukti identitas diri berupa fotokopi Kartu Tanda Penduduk (KTP), fotokopi Kartu Keluarga (KK), dan Surat Keterangan Usaha.

Beberapa persyaratan KUR Mikro s/d Rp. 5.000.000,00 yaitu calon Debitur yaitu Individu yang melakukan usaha produktif yang layak, dengan lama usaha minimal 6 bulan serta besaran kredit maksimal Rp. 5.000.000,00. Bentuk Kredit saha Rakyat di BRI Cabang Solo Kartasura yaitu KMK atau KI menurun maksimal 3 tahun. Penggunaan Agunan Kredit saha Rakyat di BRI Cabang Solo Kartasura dalam pengajuan yaitu Pokok: baik untuk KUR Modal Kerja maupun KUR Investasi adalah usaha atau tempat usaha yang dibiayai. Proyek yang dibiayai cashflownya mampu memenuhi seluruh kewajiban kepada bank (layak) dan tambahan: tidak wajib dipenuhi Bank BRI Cabang Solo Kartasura dalam pemberian KUR.

Lamanya proses pencairan dana disebabkan pula oleh penerapan asas kehati-hatian dalam menyalurkan dananya dan tetap berpegang teguh pada lima

${ }^{7}$ hasil wawancara dengan Bapak Hidayat Akbar selaku Kepala Cabang BRI Cabang Solo Kartosura, 20 Januari 2020 pukul 09.00 WIB 
prinsip dalam penilaian kondisi nasabah atau sering disebut dengan "the five of credit analysis".

\section{Lima prinsip penilaian tersebut antara lain:}

a) Character

Character adalah keadaan watak atau sifat dari debitur, baik dalam kehidupan pribadi maupun dalam lingkungan usaha. Kegunaan dari penilaian terhadap aspek character ini adalah untuk mengetahui sejauh mana kemauan dan itikad baik debitur untuk memenuhi kewajibannya sesuai dengan perjanjian yang telah ditetapkan. Character ini merupakan faktor kunci walaupun calon debitur tersebut mampu menyelesaikan hutangnya, namun kalau tidak mempunyai itikad baik tentu akan menimbulkan kesulitan pada bank di kemudian hari. Alat untuk memperoleh gambaran tentang character dari calon nasabah dapat diperoleh melalui upaya:

(1)Meneliti riwayat hidup calon nasabah,

(2)Meneliti reputasi calon debitur tersebut di lingkungan usahanya,

(3)Melakukan bank to bank information, mencari informasi dari bank ke bank lain tentang calon debitur,

(4)Mencari informasi kepada asosiasi-asosiasi usaha di mana calon debitur berada,

(5)Mencari informasi apakah calon debitur suka berjudi,

(6)Mencari informasi apakah calon debitur suka berfoya-foya.

b) Capacity

Capacity adalah kemampuan calon debitur dalam menjalankan usahanya guna memperolah laba yang diharapkan. Penilaian ini berfungsi untuk mengukur kemampuan calon debitur dalam mengembalikan hutangnya secara tepat waktu, dari usaha yang diperolehnya. Pengukuran capacity dapat dilakukan melalui berbagai pendekatan sebagai berikut:

(1)Pendekatan historis, yaitu menilai kemampuan yang telah lampau, apakah menunjukkan perkembangan dari waktu ke waktu,

(2)Pendekatan finansial, yaitu menilai latar belakang pendidikan para pengurus. Hal ini sangat penting untuk perusahaan-perusahaan yang menghendaki keahlian teknologi tinggi dan yang memerlukan profesionalisme tinggi,

(3)Pendekatan yuridis, yaitu secara yuridis apakah calon debitur mempunyai kapasitas untuk mewakili badan usaha yang diwakilinya untuk mengadakan perjanjian kredit dengan bank, 
(4)Pendekatan managerial, yaitu menilai sejauh mana kemampuan dan keterampilan nasabah melaksanakan fungsi-fungsi manajemen dalam memimpin perusahaan,

(5)Pendekatan teknis, yaitu untuk menilai sejauh mana kemampuan calon nasabah dalam mengelola faktor-faktor produksi seperti tenaga kerja, sumber bahan baku, mesin-mesin, administrasi dan keuangan, hubungan industri dan kemampuan merebut pasar.

c) Capital

Capital adalah jumlah modal sendiri yang dimiliki oleh calon debitur. Kemampuan modal sendiri diperlukan bank sebagai alat indikator kesungguhan dan tanggung jawab debitur dalam menjalankan usahanya karena ikut menganggung risiko dalam kegagalan usaha. "Biasanya jika jumlah modal sendiri (modal netto) cukup besar, perusahaan tersebut akan kuat dalam menghadapi persaingan dari perusahaan-perusahaan sejenis". Kemampuan capital ini dimanifestasikan dalam bentuk kewajiban untuk menyediakan pembiayaan sendiri dalam praktik, yang jumlahnya lebih besar daripada kredit yang dimintakan kepada bank. Bentuk pembiayaan ini tidak harus dalam bentuk uang tunai, namun juga bisa dalam bentuk barang modal, seperti: tanah, bangunan, mesin-mesin dan sebagainya.

d) Collateral

Collateral adalah barang-barang yang diserahkan debitur sebagai agunan terhadap kredit yang diterimanya. Penilaian terhadap agunan ini meliputi jenis jaminan, lokasi, bukti kepemilikkan, dan status hukumnya, untuk menghindari terjadinya pemalsuan bukti kepemilikan, maka sebelum dilakukan pengikatan harus diteliti mengenai status yuridisnya bukti pemilikan dan orang yang menjaminkan. Hakikatnya, bentuk collateral tidak hanya berbentuk kebendaan, tetapi juga yang tidak berwujud atau non material seperti jaminan pribadi (borgtocht), letter of guarantee, letter of comfort, rekomendasi, avalis.

Salah satu debitur kredit usaha rakyat di BRI Kantor Cabang Solo Kartasura mengaku bahwa pemberian kredit usaha rakyat ini benar-benar tidak disertai dengan agunan dan/atau jaminan melihat secara aspek Collateral yang dimana agunan adalah barang, aset atau surat berharga yang digunakan sebagai jaminan dalam hal ini peminjam kepada pihak pemberi pinjam (Bank) dan bertujuan untuk memberikan keamanan terhadap pinjaman yang diberikan, disatu sisi collateral bukan menjadi jaminan yang diutamakan, karena aspek collateral tersebut akan tumpang tindih dengan apa yang menjadi program pemerintah sesuai sosialisasi yang diberikan oleh Mantri mengatakan bahwa KUR ini 
merupakan program dari pemerintah untuk memberikan pertumbuhan ekonomi dari aspek UMKM di seluruh wilayah Indonesia. ${ }^{8}$

Di sisi lain, untuk penerapkan program KUR yang diberikan kepada masyarakat Bank BRI cabang Kartosuro akan tetap mengacu pada penggolongan kredit bermasalah menurut kriteria yang diberikan oleh Bank Indonesia yaitu sesuai dalam Pasal 4 Surat Keputusan Direktur Bank Indonesia Nomor 30/ 267/ KEP/ DIR, 27 Pebruari 1998, adalah sebagai berikut:

1) Kredit Lancar

2) Dalam Perhatian Khusus (Special Mention)

3) Kredit kurang lancar (Substandard)

4) Kredit Diragukan (Doubtful)

5) Kredit Macet

Ketika ada orang yang meminjam uang di bank, dari sudut pandang nasabah, hakekatnya dia tidak mengambil uang riba. Namun dia mengambil uang dari pihak yang melakukan transaksi riba. Hal ini, yang menjadikan bilamana umat Islam melakukan pinjaman uang kebank, maka keberkahan tidak datang kepadanya.

Kalangan masyarakat kelas atas tentu sangat sering melakukan pinjam meminjam uang yang bisa jadi untuk keperluan Primer dan Skunder. Kalangan bawah terutama pun juga bisa saja meminjam uang untuk sekedar memenuhi kebutuhan primernya, mulai dari makanan, kebutuhan kesehatan, pendidikan, atau kebutuhan rumah tangga lainnya. Untuk itu dibutuhkan saling membantu, dan menjauhi sifat sombong untuk tidak peduli, bahwa sifat sombong dalam islam adalah hal yang dibenci oleh Allah SWT. Dalam islam pinjam uang (hutang) adalah suatu yang tidak dilarang. Islam mengatur bahkan memperbolehkannya, asalkan bukan yang sifatnya riba dan bertentangan dengan dasar-dasar islam dalam rukun islam dan rukun iman. Aturan islam tidak ada satupun yang merugikan atau malah menjerumuskan. Untuk itulah manfaat beriman kepada Allah SWT, sampai kepada hal detil persoalan ekonomi pun islam mengaturnya. Dalam hal ini contohnya adalah masalah mawaris dalam islam (harta keluarga) dan bunga bank menurut islam.

Banyak kalangan masyarakat menganggap pinjam uang di bank merupakan perbuatan riba. Riba dalam islam QS. An-Nisa: 160 - 161 “Disebabkan kezaliman orang-orang Yahudi, kami haramkan atas (memakan makanan) yang baik-baik (yang dahulunya) dihalalkan bagi mereka, dan karena mereka banyak menghalangi (manusia) dari jalan Allah, dan disebabkan mereka memakan riba,

8 Hasil wawancara dengan Bapak Andi Prasetyo selaku mantri/ AO pada BRI Cabang Surakarta Kartosura pada 20 Januari 2020 pukul $10.30 \mathrm{WIB}$ 
padahal sesungguhnya mereka telah dilarang daripadanya, dan karena mereka memakan harta benda orang dengan jalan yang batil".

Disisi lain, bilamana dapat dipandang secara proposinal menurut hukum postif yang berlaku di Indonesia, bagaimana program Kredit Usaha Rakyat (KUR) dipandang sudut hukum islam, bahwa dengan tujuan dan maksud pemerintah memberikan subsidi kepada masyarakat yang menengah kebawah untuk meningkatkan taraf kehidupan ekonominya dengan berbagai pengawasan yang diberikan.

Pengawasan yang dilaksanakan Bank Indonesia terhadap bank dapat berupa pengawasan langsung, yaitu berbentuk pemeriksaan yang diusul dengan tindakan-tindakan perbaikan, juga dapat berupa pengawasan tidak langsung, yaitu suatu bentuk pengawasan dini melalui penelitian analitis, dan evaluasi laporan bank. Dalam rangka pengawasan yang dilakukannnya, Bank Indonesia dapat menjalankan pemeriksaan secara berkala sekurang-kurangnya satu tahun sekali untuk setiap bank. Di samping itu, pemeriksaan dapat dilakukan secara insidentil setiap waktu apabila diperlukan untuk meyakinkan hasil pengawasan tidak langsung dan apabila terdapat indikasi adanya penyimpangan.

\section{Peran OJK Mengawasi Penyaluran Kredit Usaha Rakyat (KUR) Agar Tidak Bermasalah}

Pasal 37 ayat (2) undang-undang tentang Otoritas Jasa Keuangan menentukan Otoritas Jasa Keuangan dan Bank Indonesia dapat berkoordinasi dengan bekerjasama dalam pengawasan bersama atas kegiatan jasa keuangan di bidang perbankan. Perlu dikemukakan bahwa kewenangan pengawasan Bank Indonesia terhadap perbankan merupakan bagian dari fungsi Bank Indonesia sebagaimana ditentukan dalam Pasal 8 Undang-Undang tentang Bank Indonesia.

Adapun persyaratan sebagai penyalur Kredit Usaha Rakyat berdasarkan ketentuan Peraturan Menteri Koordinator Bidang Perekonomian Republik Indonesia Selaku Ketua Komite Kebijakan Pembiayaan bagi Usaha Mikro, Kecil dan Menengah Nomor 13 Tahun 2015 tentang Perubahan atas Peraturan Menteri Koordinator Bidang Perekonomian Selaku Ketua Komite Kebijakan Pembiayaan Bagi Usaha Mikro, Kecil dan Menengah Nomor 8 Tahun 2015 tentang Pedoman Pelaksanaan Kredit Usaha Rakyat, Pasal 4 ayat (2).

Otoritas Jasa Keuangan memberikan dan mencabut izin atas kelembagaan dan kegiatan usaha tertentu bank, menetapkan peraturan, melaksanakan pengawasan bank serta mengenakan sanksi terhadap bank. Kewenangan memberikan izin (right to license), yaitu kewenangan untuk menetapkan tata cara perizinan dan pendirian suatu bank, meliputi pemberian izin dan pencabutan izin usaha bank, pemberian izin pembukaan, penutupan dan pemindahan kantor 
bank, pemberian persetujuan atas kepemilikan dan kepengurusan bank, pemberian izin kepada bank untuk menjalankan kegiatan usaha-usaha tertentu.

Kewenangan untuk mengatur (right to regulate), yaitu untuk menetapkan ketentuan yang menyangkut aspek usaha dan kegiatan perbankan dalam rangka menciptakan perbankan sehat guna memenuhi jasa perbankan yang diinginkan masyarakat. Kewenangan untuk mengawasi (right to control), yaitu:

a. Pengawasan bank secara langsung (on-site supervision)

b. Pengawasan tidak langsung (off-site supervision)

Kewenangan untuk mengenakan sanksi (right to impose sanction), yaitu menjatuhkan sanksi sesuai dengan ketentuan perundang-undangan terhadap bank apabila suatu bank kurang atau tidak memenuhi ketentuan. Tindakan ini mengandung unsur pembinaan agar bank beroperasi sesuai dengan asas perbankan yang sehat. Kewenangan untuk melakukan penyidikan (right to investigate) Sesuai dengan undang-undang OJK mempunyai wewenang untuk melakukan penyidikan di sektor jasa keuangan termasuk perbankan. Penyidikan dilakukan oleh penyidik kepolisian Negara RI dan pejabat Pegawai Negeri Sipil di lingkungan Otoritas Jasa Keuangan.

\section{Penutup}

Penelitian ini menyimpulkan, pertama, upaya Bank BRI cabang Kartosuro dalam mencegah kredit bermasalah tetap mengacu pada prinsip $5 \mathrm{C}$ dalam proses kredit yaitu: Character, Capacity, Capital, Condition and Collateral dan pada penggolongan kredit bermasalah mengacu kriteria yang diberikan oleh Bank Indonesia yaitu sesuai dalam Pasal 4 Surat Keputusan Direktur Bank Indonesia Nomor 30/ 267/ KEP/ DIR, 27 Pebruari 1998. Oleh karena kredit usaha rakyat merupakan program pemerintah dan merupakan kerjasama antara bank pelaksana dengan perusahaan penjaminan maka langkah yang diambil oleh BRI Kantor Cabang Kartasura, dalam hal ini bila dalam pelaksanaannya dilapangan terjadi kredit macet langkah yang dilakukan adalah mengajukan klaim kepada PT Askrindo dan Perusahaan Sarana Pengembangan Usaha sebagai pihak penjamin dari Pemerintah untuk penjaminan diatas sebesar $70 \%$ dari plafon, sedangkan 30\% nya ditutup oleh BRI Kantor Cabang Kartasura.

Kedua, Otoritas Jasa Keuangan dan Bank Indonesia dapat berkoordinasi dengan bekerjasama dalam pengawasan bersama atas kegiatan jasa keuangan di bidang perbankan. OJK mempunyai wewenang untuk melakukan penyidikan di sektor jasa keuangan termasuk perbankan. Kewenangan untuk mengawasi (right to control) ini meliputi pengawasan bank secara langsung (on-site supervision) dan pengawasan tidak langsung (off-site supervision) 


\section{Daftar Pustaka}

\section{Buku}

Adolf, Huala, Hukum Perdagangan Internasional, Raja Grafindo Persada, Jakarta, 2013.

Budiono, Herlien, Asas Keseimbangan bagi Hukum Perjanjian Indonesia, Cetakan ke1, Bandung, 2006.

G. Luckett, Dudley, Uang dan Perbankan, edisi ke 2, Erlangga, Jakarta, 1994.

H.S, Salim, Hukum Kontrak Teori dan Teknik Penyusunannya, Sinar Grafika, Jakarta, 2003.

Perkembangan Hukum Kontrak Innominaat di Indonesia, Sinar Grafika, Jakarta, 2003.

Hermansyah, Hukum Perbankan Nasional Indonesia, Cetakan ke-6 Kencana, Jakarta, 2011.

Iskandar, Syamsu, Bank Dan Lembaga Keuangan Lain, SAB, Jakarta, 2008.

Khozim, M., Sistem Hukum Prespektif Ilmu Sosial, ctk Kelima, Nusa Media, Bandung, 2013, “Terjemahan dari : Lawrence M. Friedman, The Legal System a Social Science Prespective, Russel Sage Foundation, New York, 1975".

Mertokusumo, Sudikno, Teori Hukum, ctk Keenam, edisi revisi, Cahaya Atma Pustaka, Yogyakarta, 2012.

P. Sugarda, Paripurna, Ringkasan Disertasi Pengaturan Sistem Pengawasan Perbankan Berdasarkan Prinsip Kehati-hatian di Indonesia, Universitas Gadjah Mada; Yogyakarta, 2012.

Soekanto, Soerjono, Pengantar Penelitian Hukum, ctk Ketiga, UI Press, Jakarta, 2012.

Suyatno, Thomas, et al., Dasar-dasar Perkreditan, PT. Gramedia Pustaka Utama, Jakarta, 2003.

\section{Internet}

Tony Rodyanto, 2014, “Pengawasan Terintegrasi Lembaga Jasa Keuangan Suatu Tinjauan Umum" https://tonyrodyanto.wordpress.com/2014/09/08/ pengawasan-terintegrasilembaga-jasa-keuangan-suatu-tinjauan-umum/. Diakses pada 12 Oktober 2014.

Lihat web kementerian keuangan republik indonesia diakses pada tanggal 2 oktober 2019 pukul 23.00 https://www.kemenkeu.go.id/publikasi/ artikel-dan-opini/evaluasi-kredit-usaha-rakyat-kur-2018/

Lihat Undang-undang Negara Republik Indonesia Nomor 10 Tahun 1998 tentang Perbankan,

http:/ / gudangpengertian.blogspot.co.id/2014/10/pengertian-bank-secaraumum-dan-menurut.html di akses pada tanggal 28 Mei 2018.

https://www.ojk.go.id/id/kanal/perbankan/Pages/Bank-Syariah.aspx diakses pada tanggal 28 Mei 2018 
https://www.bi.go.id/id/perbankan/ikhtisar/pengaturan/sistem-pengawasan bank/Contents/Default.aspx diakses pada tanggal 28 Mei 2018.

(http://id.shvoong.com/businessmanagement/investing/2195291-pengertian-kreditbermasalah/\#ixzz1gbv4SOTP diakses pada Sabtu, 31 Mei 2018, 17:01) 